\title{
Impact of Alleyway and In-row Planted Groundcovers in Midwestern Vineyard
}

\author{
Benjamin Allen Loseke*, Paul Eugene Read, Stephen Joseph Gamet
}

Department of Agronomy \& Horticulture, University of Nebraska, Lincoln, Nebraska, USA

Email address:

Bloseke2@unl.edu (B. A. Loseke)

${ }^{*}$ Corresponding author

\section{To cite this article:}

Benjamin Allen Loseke, Paul Eugene Read, Stephen Joseph Gamet. Impact of Alleyway and In-row Planted Groundcovers in Midwestern Vineyard. American Journal of Agriculture and Forestry. Vol. 9, No. 3, 2021, pp. 131-140. doi: 10.11648/j.ajaf.20210903.16

Received: April 16, 2021; Accepted: May 14, 2021; Published: May 27, 2021

\begin{abstract}
In many Midwestern vineyards a one meter weed-free strip is maintained directly beneath the vines to reduce vine-weed competition. Conventionally, this strip has been conserved with repeated applications of herbicide, mainly glyphosate. The necessity for this weed-free strip to reduce vine-weed competition has been well documented in more arid climates. However, in areas with higher soil fertility and adequate rainfall grapevines can become overly vigorous and competition with a groundcover (GC) has been shown to be a useful tool to alleviate excess growth. Moreover, stand establishment and early vine growth have not been well documented when planting GC immediately following the vine planting. The main objective of this project was to assess the severity of competition for water between 'Edelweiss' grapevines and neighboring permanent GC treatments. In year one (2014), the vineyard and GCs were established, where the GCs were planted immediately after the vines. Generally, GC treatments had lower Midday Leaf Water Potential ( $\left.\Psi_{\mathrm{md}}\right)$ than the herbicide sprayed control, however, none of the treatments exhibited even slight water stress between 2015 and 2017. Vine-GC competition was most apparent in the three years of pruning weights, where the most native grass GC treatment had an average of $158 \%$ lower weights than the control. Results suggest that planting specific groundcovers in both the alleyways and in-row areas of the vineyard during the first year of establishment can be overly detrimental to vine growth and causes reduced yields but other groundcovers can be a useful alternative to chemical weed control.
\end{abstract}

Keywords: Grape, Vineyard, Groundcover

\section{Introduction}

In 2010, more than 400,000 pounds of Roundup were applied to wine grapes (Vitis spp.) in California alone. And with over 280 million pounds of glyphosate sprayed in the United States annually, chemical weed control in agriculture has become heavily scrutinized due to the extensive use of this herbicide [1]. The usage of glyphosate in agriculture has been linked to many health issues including cancer [2], as well as Parkinson's disease, infertility, and fatal kidney disease [3]. Moreover, long-term problems with herbicides include accumulation in the soil, which can damage vine roots, contaminate surface water through runoff, and leach into groundwater [4]. Herbicide resistance in target weeds has also become a threat to effective weed control. For example, glyphosate-resistant Amaranthus palmeri (Palmer Amaranth) has been found on agricultural land in Nebraska [5].
The benefits of planting groundcovers in the vineyard extend far beyond reducing the use of herbicides. Permanent groundcovers have been shown to increase soil erosion protection, water infiltration, and organic matter, while also reducing soil crusting and soil temperature in the vineyard [6, 7]. Bare soil, whether from herbicide applications or cultivation, increases the intensity of runoff and erosion [8]. The necessity for research investigating reduced pesticide strategies in all agricultural crops, including grapes, is becoming increasingly important.

Herbicide use in the vineyard is generally focused on controlling weeds in the one-meter-wide swath directly beneath the vines. Studies have shown that cover crops and groundcovers planted in this area can limit vine growth and productivity [9-11], which results in the recommendation to keep this area free of weeds. Only recently, it has been recognized that planting cover crops and/or groundcovers in 
this zone may be beneficial to the vines. However, both optimum timing and recommendations for groundcover species are still widely unknown.

In areas that receive moderate to heavy amounts of rain (such as Southeast Nebraska with $>76 \mathrm{~cm}$ annual rainfall), and have highly fertile soils, overly vigorous growth is common in many grape cultivars [12]. Grapevines have an indeterminate growth habit where vegetative growth is not reduced by a shortening photoperiod, but rather continues as long as sufficient heat, nutrients, and moisture are available [13]. 'Overly vigorous' is characterized by vines that have large, dense canopies, which result in low light penetration [14] and shade the fruit zone, which in turn compromises fruit quality. Additionally, excessive shading can delay veraison and fruit maturation, causing reduced soluble solids ( ${ }^{\circ}$ Brix) and anthocyanin concentrations as well as increased concentrations of undesirable flavor compounds such as methoxypyrazines $[15,16]$. Overly vigorous vines may also have a problem not reaching full dormancy in the late fall, which can then lead to reduced cold hardiness [17]. Finally, dense canopies reduce air flow as well as light infiltration into the canopy, thus increasing disease pressure and reducing spray penetration and effectiveness of fungicide applications [18]. The main methods to increase light and air penetration into the canopy are shoot and cluster thinning, hedging, leaf removal, and lateral shoot pulling. However, these practices require significant amounts of labor and time [19]. Using groundcovers and cover crops to maintain a slight-tomoderate water deficit can be highly beneficial in grapevine cultivation because it stimulates optimal quality parameters without significantly compromising yield $[12,20]$.

In this paper, we evaluate four different native grass and legume groundcover mixtures and their effect on growth and yield of neighboring 'Edelweiss' grapevines in one commercial vineyard in Southeast Nebraska. Groundcovers were established immediately after the vineyard was planted to evaluate the impact on young vines. However, this method of planting groundcovers is atypical since groundcovers are typically planted after the grapevines have had two to three years to become established. The failure to control weeds during the first year of vineyard establishment has been shown to greatly reduce vine growth and to even delay fruit production by a year or more until the vines reach full production [21].

\section{Materials and Methods}

\subsection{Experimental Description and Design}

This study was conducted from 2014 to 2018 in a commercial sample vineyard at 'Oak Creek Vineyards' in Southeast Nebraska $\left(40.947450^{\circ} \mathrm{N},-96.766140^{\circ} \mathrm{W}\right)$. 'Edelweiss' ('Minnesota 78 x Ontario') grapevines were chosen due to their popularity amongst grape growers, wineries, and consumers across the cool climate of the American Midwest. This cultivar has a vigorous growth habit, which in some vineyards can become problematic for growers, as excessive growth can shade the fruiting zone and thereby increase labor costs through additional leaf pulling, shoot thinning, and more intense pruning. Bare-rooted 'Edelweiss' plants procured from 'Double A Vineyards' in Northwest New York were planted in May 2014. 'Blue-X' grow tubes were placed around the young plants after planting and left in place until fall of that year. Vines were trained to a $1.83 \mathrm{~m}$ high-wire trellis system with a spacing of $2.44 \mathrm{~m}$ between plants and $3.66 \mathrm{~m}$ between rows, with row orientation North to South. The predominate soil types are Aksarben silty clay loam, Pawnee clay loam, and Yutan silty clay loam (Web Soil Survey, 2018). Change in elevation occurs from East (293 m AMSL) to West (385 m AMSL) across the vineyard.

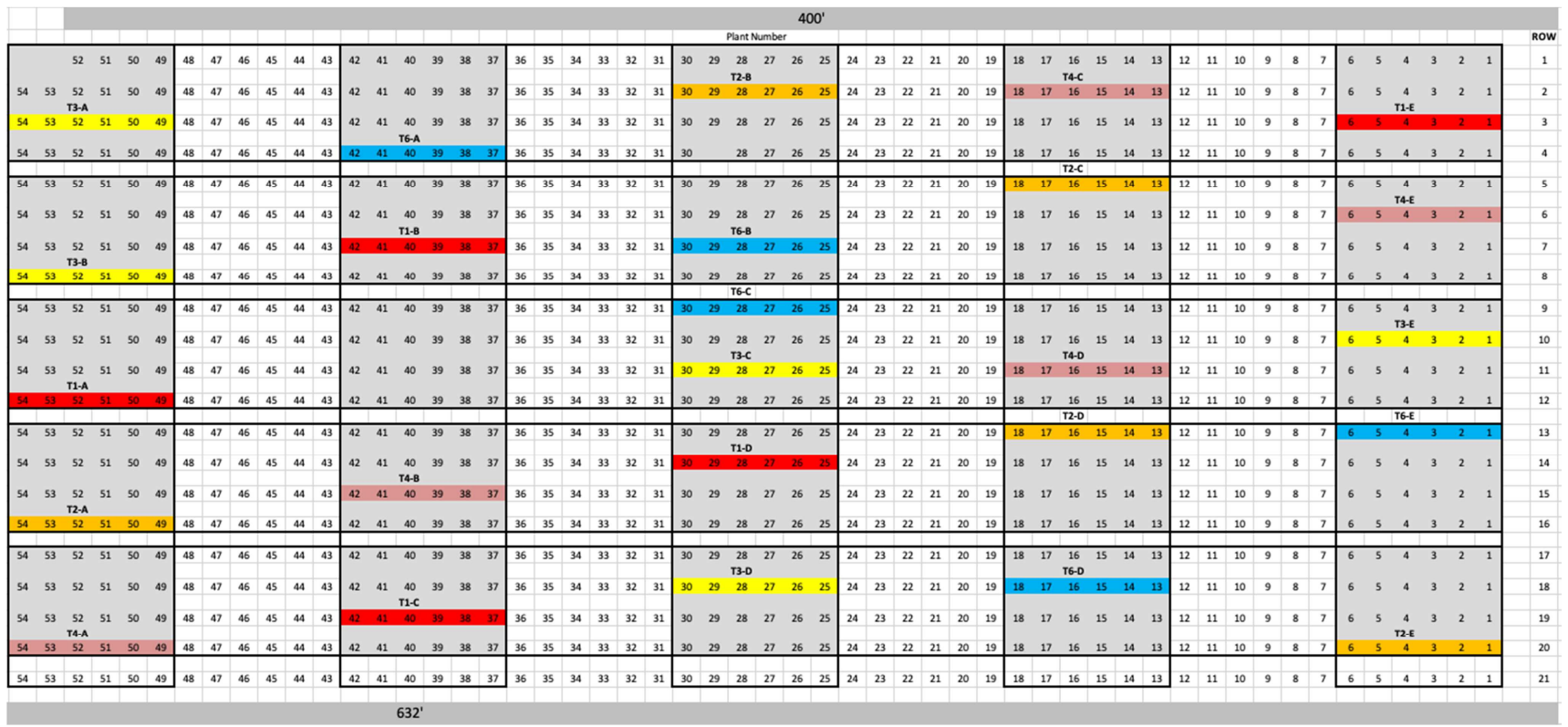

Figure 1. Layout of experiment and treatments at Oak Creek Vineyards. Blocking occurs from top to bottom to account for change in slope and soil types. Each replicate consisted of six plants, with one buffer plant on either end of the replicate and four plants in the middle used for data collection. Trt $1-$ Red, Trt 2 -Orange, Trt 3 -Yellow, Trt 4-Pink, Control-Blue. 
Groundcover seed was procured from 'Stock Seed Farms' in Southeast Nebraska. The selection of species in each groundcover mixture was based on the following factors: rate of establishment, water usage, native range in the Midwest, ability to grow in compacted soils, and low-growth habit. The experiment consisted of four groundcover treatments (Trt 1, Trt 2, Trt 3, and Trt 4), and a herbicide sprayed control treatment. The treatments were comprised of: Trt 1 - Western Yarrow (Achillea millefolium), Birdsfoot Trefoil (Lotus corniculatus), White Clover (Trifolium repens); Trt 2 - Hard Fescue (Festuca brevipila), Sheep's Fescue (Festuca ovina), Sideoats Grama (Bouteloua curtipendula), Texoka Buffalograss (Buchloe dactyloides), Blue Grama (Bouteloua gracilis); Trt 3 - Kentucky Bluegrass (Poa pratensis), White Clover (Trifolium repens), Red Fescue (Festuca rubra), Hard Fescue (Festuca brevipila), Chewing's Fescue (Festuca rubra ssp. commutata), Perennial Ryegrass (Lolium perenne); and Trt 4 - Texoka Buffalograss (Buchloe dactyloides). The control treatment were a $1 \mathrm{~m}$ under-trellis herbicide treated strip combined with natural vegetation growing in adjacent interrows.

Groundcovers were established in May 2014 under the trellis and in adjacent interrows on either side of the study rows in a randomized complete block design. Four-row blocks were used from East to West to account for differences in elevation and soil type. All groundcover treatments were randomly assigned within each block and replicated five times. The groundcovers were seeded following the vineyard planting; and the soil was prepared using a soil conditioner attached to a skid loader. Once the ground was level and free of large clods, the grass seed mixtures were loaded into a native grass seed drill set at 20 $\mathrm{cm}$ spacing between rows. The under-trellis areas were handseeded and incorporated into the soil using a hard rake, as the drill would not fit between plants. Plots were rolled and compacted with a Fimco landscape roller to increase seedsoil contact, and were then immediately watered. To ensure a dense and uniform stand, seeding rates were: $21.8 \mathrm{lbs} /$ acre (Trt 1), $30.0 \mathrm{lbs} /$ acre (Trt 2), $100.0 \mathrm{lbs} /$ acre (Trt 3), and 130.7 lbs/acre (Trt 4).

Precipitation can be highly inconsistent in late spring and summer in Nebraska; hence, it was important to install drip irrigation to provide the young vines with supplemental water. Additionally, groundcover plots were irrigated to speed up establishment, outcompete resident weed populations, and reduce soil erosion from heavy spring rains. An overhead irrigation system was used for groundcover plot establishment. Groundcover plots were watered for 30 minutes every other day just before dawn throughout the first growing season. The inter-rows were mowed every other week throughout the growing season with a rotary mower and the cut material left in place. The under-trellis groundcovers were allowed to grow and were not managed.

\subsection{Groundcover Measurements}

Data collection during the first year was primarily focused on the rate of establishment of each groundcover treatment. The speed of establishment is important as groundcovers reduce the resident weed seed population's ability to become established. Rate of establishment was assessed weekly (beginning July 7, 2014) by placing a 61 x $61 \mathrm{~cm}$ PVC square on the ground in two specific locations within each replication. These locations were randomly chosen at first and then monitored weekly. Location 1 was within the interrow and Location 2 under the trellis. A digital image was taken of the PVC square in each of the locations. The images were processed using 'Click to Crop,' where all pixels outside of the PVC square were removed from the image. Images were then analyzed using the University of Nebraska's Center for Advanced Land Management Information Technologies' VegFraction software, which compared the percent of green vs. non-green material within each image. The rate at which the percentage of green vs. non-green material in each image increased over the growing season was used as an indicator for the rate of groundcover establishment.

\subsection{Grapevine Measurements}

To assess how groundcover treatments affected grapevine water status, vine water potential was measured as mid-day leaf water potential $\left(\Psi_{\mathrm{md}}\right)$ with a Soil Moisture Equipment 2005 HGPL pressure chamber beginning on June 30, 2015, and repeated weekly throughout the growing season. Midday measurements occurred as close to solar noon as possible $(12: 30-2: 30 \mathrm{pm}, \mathrm{CDT})$ when the vines were at a peak water stress level. Fully expanded, sunlit leaves were covered with a plastic bag, quickly sealed, and then petioles cut within 2 seconds. The time from leaf excision to the pressure chamber measurement was generally less than 10 seconds. This process was repeated in 2016 and 2017; and pruning weights were measured on March 17, 2015, February 17, 2016, and February 16, 2017. Vines were pruned leaving 4 to 5 buds on each cane. Prunings were collected and weighed from the four center plants within each replication.

Performance of 'Edelweiss' grapevines was assessed by measuring grape yield and cluster number per vine at harvest (all treatments were hand-harvested on the same date), which occurred on August 10, 2016 and August 15, 2017. Using these data, average cluster weight was also calculated. Berry samples of 100 berries each were taken from each plant and were frozen to be later analyzed for $\mathrm{pH}$, TA and ${ }^{\circ}$ Brix. The berry analysis was conducted on September 15, 2016 and September 19, 2017. The samples were removed from the freezer the day before testing and placed in a cooler set to $4.5{ }^{\circ} \mathrm{C}$ to thaw. On the day of testing, the berries were removed from the cooler and warmed to room temperature. The samples were then crushed within the plastic freezer bag and the juice was extracted through a cut hole into a $100 \mathrm{ml}$ beaker [22], which was then poured into test tubes for further analysis. Juice $\mathrm{pH}$ was measured with a Hanna Instruments pH/ORP meter model HI 2211. Soluble solids ( ${ }^{\circ}$ Brix) content was measured using an Atago USA PR-101 digital 
refractometer. TA was determined with the use of a Hanna Instruments HI 900 automated titration system.

Soil samples were collected in the spring of 2015, 2016, and 2017 before the grapevines broke dormancy. Samples were taken at a depth of $30 \mathrm{~cm}$ from each replication in the vineyard. Each sample consisted of a composite of six random subsamples within each replication: two taken from the inter-rows on each side of the vine row, and two taken from under the trellis. Samples were analyzed by 'AgSource' laboratories in Lincoln, $\mathrm{NE}$ for $\mathrm{pH}, \mathrm{EC}$, organic matter, and a variety of nutrients.

\subsection{Statistical Analysis}

All data $\left(\Psi_{\mathrm{md}}\right.$, harvest, pruning weights, soil samples, and bud break) were treated as a Randomized Complete Block Design with a Two-Way ANOVA using the GLIMMIX procedure. Main and simple effects were compared at $\mathrm{P} \leq 0.05$, when appropriate. A repeated measure covariance structure was also fit to the residual of each model for $\Psi_{\mathrm{md}}$ to account for the dependencies imposed by sampling over time. In 2015 and 2016 the ANTE(1) covariance structure was used and in 2017 the SP(POW) structure was used to accommodate unequally spaced collection dates in the three years. Data were analyzed using SAS/STAT software version 9.2.

\section{Results}

\subsection{Environmental Conditions During Experimental Years}

Environmental data from the vineyard weather station indicated the 2016 growing season was warmer than 2014, 2015, and 2017 , averaging $18.7^{\circ} \mathrm{C}$, whereas 2014,2016 , and 2017 averaged $17{ }^{\circ} \mathrm{C}, 17.7{ }^{\circ} \mathrm{C}$, and $17.7{ }^{\circ} \mathrm{C}$, respectively. Precipitation was the highest in 2017 with $89 \mathrm{~cm} ; 2014$ and 2015 had very similar precipitation totals $(81.8$ and $83.6 \mathrm{~cm}$ inches) and 2016 had the lowest total precipitation with 63.5 $\mathrm{cm}$. Heavy and fast rainfall events in May of 2015 caused fairly severe soil erosion in parts of the vineyard that had no groundcover.

\subsection{Grapevine Water Use}

In many growing regions across the world, vines are grown for wine production without the supplementation of irrigation. Under dry conditions when a relatively small amount of water supplements the vines, a large increase in grape production can occur [23-26]. However, it is generally thought that wine quality is diminished with increased irrigation and berry size. Due to this, a full irrigation regime is seldom applied to wine grape vineyards [27]. The most common irrigation practice is to apply only enough water to keep the vines from becoming moderately to seriously water stressed. Maintaining a mild water stress during the final stage of berry development increases the proportion of skin to grape juice, thus improving wine color and flavor [28].

Leaf water potential (LWP) thresholds have been defined for vinifera grapevines byWilliams, L., \& Araujo, F. [29]; Choné, X., Van Leeuwen, C., Chéry, P., \& Ribéreau-Gayon,
P. [30] and Grimes, D., \& Williams, L. [31]. Generally, in California it is advised that irrigation should be initiated when $\Psi_{\mathrm{md}}$ levels reach -10 bars, where -15 to -16 bars is the lowest $\Psi_{\text {md }}$ value achieved under dry conditions. There have not been any $\Psi_{\text {md }}$ thresholds established for many of the grape cultivars grown in the Midwestern United States, including 'Edelweiss' which was used in this project. Midday leaf water potential was measured in 2015, 2016, and 2017 to observe the effects different groundcover treatments had on the water status of neighboring 'Edelweiss' grapevines. Because environmental conditions varied greatly between years, comparisons between treatments across the three years was not possible. Therefore, the treatments were only compared within each individual year.

In 2015 , there was not a treatment*date interaction so the data were averaged across all dates for each individual treatment. The only significant difference in $\Psi_{\text {md }}$ was between Trt 2 and Trt 4, where Trt 2 had a lower $\Psi_{\text {md }}$. There was only one instance where a treatment was statistically different from the control in 2015 which was on July 29, when Trt 1 had a higher $\Psi_{\text {md }}$ of 1.79 bars. Besides this, there were no significant differences amongst the groundcover treatments and the herbicide sprayed control indicating that in 2015 the groundcovers did not reduce the availability of water to their neighboring grapevines, thus inducing water stress.

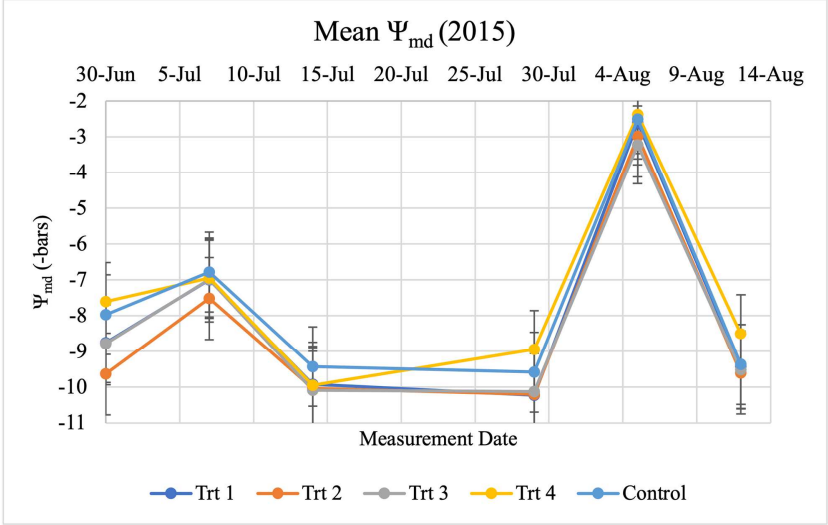

Figure 2. Plot of midday leaf water potential $\left(\Psi_{m d}\right)$ collected weekly from 'Edelweiss' grapevines from June 30 to August 12, 2015.

The four groundcover treatments and the control showed a similar pattern of change in $\Psi_{\text {md }}$ across all measurement dates in 2015, however, there were clear differences in $\Psi_{\mathrm{md}}$ between the sample dates (Figure 2). Drastic differences in $\Psi_{\mathrm{md}}$ between dates can be seen, with high and low $\Psi_{\mathrm{md}}$ throughout the summer from mean $\Psi_{\text {md }}$ data. Most apparent was the change on August 15 when $\Psi_{\text {md }}$ was only -2.7 bars. $\Psi_{\text {md }}$ values on all other dates ranged from -7 to -9.8 bars. This can be explained by the rainfall event that happened the day before data collection and the cooler temperatures (23.9$26.7{ }^{\circ} \mathrm{C}$ ) on the day of collection. On this date, the grapevines exhibited no water stress and the stomata would have all been fully open and transpiration was occurring at full capacity. The two dates that exhibited the lowest water potential in 2015 were July 14 and 29 where vines had an 
average water potential of -9.8 bars. If these grapes were managed using standard California $\Psi_{\mathrm{md}}$ thresholds, irrigation would not even have been turned on in 2015 .

In 2016 similar to what was observed in 2015 there was no interaction between the treatment and date. Generally speaking the treatments followed the same pattern across all collection dates, but in a few cases the treatment curves crossed indicating a possible interaction (Figure 3). For example, on August $1^{\text {st }}$, Trt 1 is at the bottom of the $\Psi_{\mathrm{md}}$ values but then jumps to the top on August $10^{\text {th }}$.

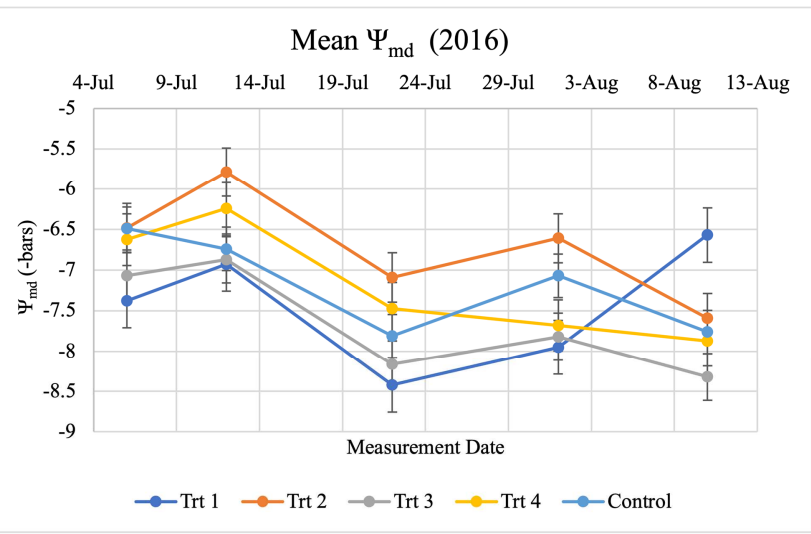

Figure 3. Plot of midday leaf water potential $\left(\Psi_{m d}\right)$ collected weekly from 'Edelweiss' grapevines from July 06 to August 10, 2016.

When the data from each treatment are averaged across all dates a very small difference is observed in $\Psi_{\mathrm{md}}$, with the lowest being Trt 3 ( -7.6 bars) and the highest being Trt 2 (6.7 bars). This is only a difference of 1.1 bars and would typically be insignificant to the grape grower, especially since these vines did not appear to be water stressed at these $\Psi_{\text {md }}$ levels. The statistics indicate that there are only two instances where treatments are significantly different from one another. Trt 2 had a significantly higher $\Psi_{\mathrm{md}}$ compared to Trt 1 and Trt 3. Moreover, in 2016 the groundcover treatments did not statistically have higher or lower $\Psi_{\mathrm{md}}$ than the herbicide sprayed control indicating the groundcovers water usage did not impact vine water needs.

In 2017, it appeared that there was a very strong interaction between the treatments and the measurement dates. Generally speaking most of the treatments showed more negative $\Psi_{\mathrm{md}}$ than the control, especially as the season progressed. Trt 1 had the lowest $\Psi_{\text {md }}$ throughout the entire season. Figure 4 indicates that from July 14 to July 27, 2017 there was a dry period in the vineyard. The $\Psi_{\text {md }}$ during these weeks of all treatments consistently declined. Interestingly, the control showed a less sharp drop in $\Psi_{\text {md }}$ during this dry period than the vines growing alongside groundcovers. As the season progressed, all of the groundcover treatments were significantly different from the control. At this point in the study the 'Edelweiss' vines had been growing within their groundcovers for three years and began to exhibit the negative effects of water competition. The dry period in 2017 revealed the competition for limited water between the vines and groundcovers in the $\Psi_{\text {md }}$ measurements. Although, if the goal is to keep the vines moderately water stressed and control vine vigor, then groundcover treatments would be considered beneficial in this situation.

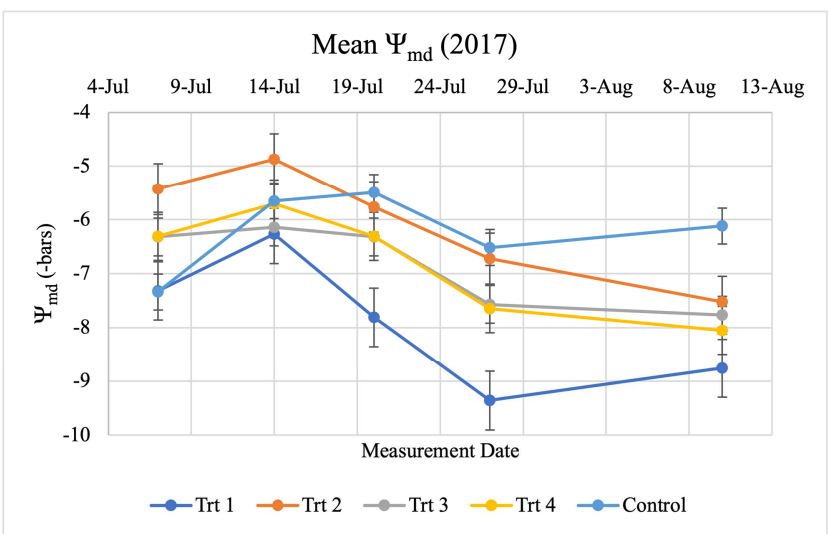

Figure 4. Plot of midday leaf water potential $\left(\Psi_{m d}\right)$ collected weekly from 'Edelweiss' grapevines from July 07 to August 10, 2017.

\subsection{Grapevine Growth}

Pruning weights have a direct relationship with vegetative growth in the year prior to pruning. Pruning weight measurements are used in conjunction with yield measurements to calculate yield-to-pruning weight ratios [32]. These indices are representations of the vegetative and reproductive balance and can be used as an indirect measurement of fruit quality [19]. Pruning weights were collected in the winter of 2016 and 2017, i.e. the growing season of 2015 and 2016, respectively. The second growing season was 2015 and the third was 2016, as well as the first harvest year. It would be expected that the vegetative growth would increase dramatically across all treatments from the second to third year of growth. Interestingly, this was not the case in any of the groundcover treatments. The control was the only treatment that showed significantly greater pruning weights from 2015 to 2016 (0.13 kg up to $0.23 \mathrm{~kg}$ ) (Figure 5). The pruning weights of vines in Trt 2 actually decreased from 2015 to 2016 (0.06 $\mathrm{kg}$ down to $0.04 \mathrm{~kg})$. In 2015, the vines that were grown with a chemically controlled strip (control) had the highest pruning weights when compared to the four groundcover treatments. The control vines had an average of $0.14 \mathrm{~kg}$ per vine and the four groundcover treatments ranged from $0.05 \mathrm{~kg}$ to $0.11 \mathrm{~kg}$ per vine, with the greatest being Trt 4 and the lowest being Trt 1, however there were not significant differences among any of the treatments. Trt 1 and Trt 3 both had significantly lower pruning weights compared to the control. In 2016, a similar pattern emerged where the control had 193\% higher pruning weights than the vines growing under the native grass groundcover treatment (Trt 2). The other three-groundcover treatments had reduced pruning weights ranging from $20 \%$ to $136 \%$. The control had an average of $0.23 \mathrm{~kg}$ of growth per plant. Trt 2 (native grass) had the lowest pruning weights at $0.005 \mathrm{~kg}$ per plant. All of the treatments with the exception of Trt 4 had significantly lower pruning weights than the chemically maintained control. 


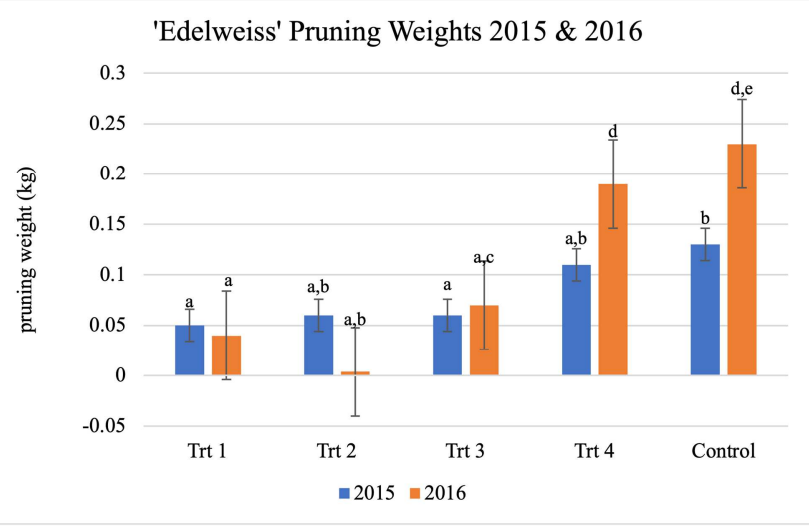

Figure 5. Chart of pruning weights in 2015 and 2016. Data were collected in winter of 2016 and 2017, respectively.

*Columns in the same year with same letters are not significantly different at $p \leq 0.05$.

\subsection{Grapevine Fruit Production and Berry Analysis}

All vines within each treatment showed an increase in number of clusters from 2016 to 2017 . The largest change from year to year was found in the control treatment which increased from 51 clusters per plant to 150 clusters per plant. Trt 1 increased from 46 clusters per plant to 112 clusters, Trt 2 - 32 clusters to 54 clusters, Trt 3 - 53 clusters to 116 clusters and Trt $4-61$ clusters to 106 clusters. No significant differences were observed between treatments in 2016. In 2017, there were four treatment comparisons that showed statistically significant differences. Trt 2 had fewer clusters than all of the other treatments (Trt 1, 3, 4, and control) (Table 1). This was expected as visual difference between Trt 2 and the rest was quite obvious in the number of clusters that were present on each plant.

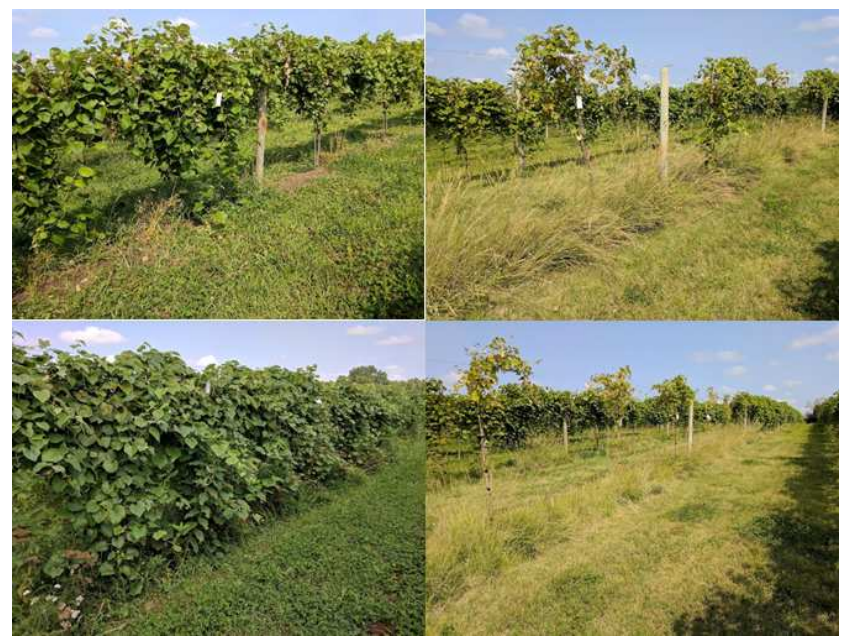

Figure 6. Side by side comparison of vines at time of harvest in 2017. The herbicide sprayed control (top and bottom left) has significantly more canopy than the native grass treatment (top and bottom right).

Table 1. Measured values for average number of clusters per vine, total cluster weight, average cluster weight, average weight of a single berry, soluble solids ('Brix), pH and titratable acidity (TA) in 2016 and 2017. Trt 1 = Western Yarrow, Birdsfoot Trefoil and Dutch Clover; Trt $2=$ Hard Fescue, Sheep's Fescue, Sideoats Grama, Buffalograss and Blue Grama; Trt $3=$ KY Bluegrass, White Clover, Red Fescue, Hard Fescue and Chewing's Fescue; Trt $4=$ Texoka Buffalograss; Control $=$ weeds controlled by herbicide under-row.

\begin{tabular}{|c|c|c|c|c|c|c|c|}
\hline & Cluster Number & Avg Vine Yield (g) & Avg Cluster Weight (g) & Avg Berry Weight (g) & ${ }^{\circ}$ Brix & pH & TA \\
\hline \multicolumn{8}{|l|}{2016} \\
\hline Trt 1 & $46.1 \mathrm{a}$ & $2709.6 \mathrm{a}$ & $58.6 \mathrm{a}$ & $1.8 \mathrm{a}$ & $15.8 \mathrm{a}, \mathrm{b}$ & 3.2 & $10.3 \mathrm{a}$ \\
\hline Trt 2 & $32.3 \mathrm{a}$ & $2575.1 \mathrm{a}$ & $58.0 \mathrm{a}$ & $1.8 \mathrm{a}$ & $15.8 \mathrm{a}, \mathrm{b}$ & 3.2 & $10.3 \mathrm{a}$ \\
\hline Trt 3 & $53.3 \mathrm{a}$ & $2345.1 \mathrm{a}$ & $57.5 \mathrm{a}$ & $1.8 \mathrm{a}$ & $15.9 \mathrm{a}, \mathrm{b}$ & 3.2 & $10.2 \mathrm{a}$ \\
\hline Trt 4 & $60.9 \mathrm{a}$ & $2345.1 \mathrm{a}$ & $58.6 \mathrm{a}$ & $1.8 \mathrm{a}$ & $15.9 \mathrm{~b}$ & 3.2 & $10.0 \mathrm{a}$ \\
\hline Control & $51.2 \mathrm{a}$ & $2382.1 \mathrm{a}$ & $59.1 \mathrm{a}$ & $1.8 \mathrm{a}$ & $16.0 \mathrm{a}$ & 3.2 & $10.0 \mathrm{a}$ \\
\hline \multicolumn{8}{|l|}{2017} \\
\hline Trt 1 & $112.0 \mathrm{a}$ & $4989.5 \mathrm{a}$ & $43.7 \mathrm{a}, \mathrm{b}, \mathrm{d}$ & $2.3 \mathrm{a}$ & 18 & 3.4 & $7.6 \mathrm{a}, \mathrm{b}$ \\
\hline Trt 2 & $52.4 \mathrm{~b}$ & $1583.0 \mathrm{~b}$ & $29.1 \mathrm{a}, \mathrm{b}$ & $2.0 \mathrm{a}$ & 17.1 & 3.3 & $8.5 \mathrm{~b}$ \\
\hline Trt 3 & $118.0 \mathrm{a}$ & $5302.5 \mathrm{a}, \mathrm{c}$ & $56.0 \mathrm{c}, \mathrm{d}$ & $2.1 \mathrm{a}$ & 18.2 & 3.5 & $6.5 \mathrm{a}$ \\
\hline Trt 4 & $105.6 \mathrm{a}$ & $4136.8 \mathrm{a}, \mathrm{b}$ & $36.3 \mathrm{a}$ & $2.0 \mathrm{a}$ & 15.7 & 3.4 & $8.2 \mathrm{~b}$ \\
\hline Control & $150.5 \mathrm{a}$ & $7833.5 \mathrm{c}$ & $49.9 \mathrm{~d}, \mathrm{c}$ & $2.1 \mathrm{a}$ & 17 & 3.4 & $8.2 \mathrm{~b}$ \\
\hline
\end{tabular}

*Values with the same letter in the same column indicate no statistical differences at $p \leq 0.05$.

From 2016 to 2017 the average cluster weight increased significantly in all of the treatments with the exception of Trt 2 , which actually decreased. In 2016, Trt 2 had an average yield of 1848.2 grams and dropped to 1682.6 grams in 2017. This result is concerning because a drop in yield from the second to third year is the opposite of what's expected. 'Edelweiss' grapevines should yield 9-14 kg per plant after the third or fourth year they are planted. For example, the control yielded 3040 g per plant in 2016 and jumped up to $7833 \mathrm{~g}$ in 2017 , which would be the typical expectation for 'Edelweiss' vines.

Statistically, there were no differences in total yield between treatments in 2016 . However, Trt 2 produced far less fruit than all of the other treatments and still should be considered important, especially after seeing the results from 2017, when Trt 2 yields decreased from 2016. In 2017, Trt 2 had significantly lower yields than all other treatments and the control with the exception of Trt 4 . Trt 1, Trt 2, and Trt 4 all had lower yields than the control. The only groundcover treatment that was not different from the control was Trt 4, which was grown as a control in the first year and then was converted to a Texoka Buffalograss groundcover treatment in the year following the grapes being planted (2015). This is one indication that planting a groundcover after the vines have one year to establish may limit the amount of competition between the vines and groundcovers resulting in 
higher yields.

Similar to yield, there were no differences between treatments in average cluster weights in 2016. In 2017, the average cluster weight dropped for all treatments and showed lower average weights than in 2016, however total yields increased from 2016 to 2017. A drop in cluster weight but an increase in total yield typically indicated more clusters thus reducing the mean weight. This is proven by the cluster number data which show a large increase in cluster number from 2016 to 2017. Increased cluster numbers can result from a variety of factors but most likely it was caused by more buds left at pruning than in the previous year and/or an environmental event caused vines to grow and produce additional clusters from secondary buds (hail, wind, herbicide drift, etc.). Lastly, Trt 2 produced 54\% less fruit than the control in 2017.

'Edelweiss' grapes are typically harvested before they are phenologically ripe when used for wine production. The level at which they are typically harvested is between 14 and $16^{\circ}$ Brix, depending on the winery's preference. In 2015, the fruit ranged from $15.1{ }^{\circ} \mathrm{Brix}$ (Trt 4) to $16.3{ }^{\circ} \mathrm{Brix}$ (control) and all samples fell within the recommended range (Table 1). Trt 4 had a lower ${ }^{\circ}$ Brix than the control, however the difference was small and would not likely be considered significant to the wine maker. Soluble solids were higher amongst all treatments in 2017 ranging from $15.7^{\circ}$ Brix (Trt 4) to $18.2{ }^{\circ}$ Brix (Trt 3) and exceeded the typical level wanted by a winery. However, the winemaker made the ultimate decision on when to pick these grapes. Trt 4 was again significantly lower than the control in 2017 and treatments 1 , 2 and 3 also all had significantly higher ${ }^{\circ}$ Brix than Trt 4 .

The optimum juice $\mathrm{pH}$ range for producing white wine with grapes grown in the Midwest is $3.2-3.4$ [33]. In 2016, juice $\mathrm{pH}$ in all of the treatments was slightly lower than the recommended range at 3.2. $\mathrm{pH}$ values in 2017 were higher than in 2016 with $\mathrm{pH}$ levels ranging from 3.3 to 3.5 . Trt 2 and Trt 4 had lower juice $\mathrm{pH}$ than the control; however both were still within the recommended range. Although some statistical differences were within $\mathrm{pH}$, the value of this is diminished because all samples would still be considered satisfactory by the winemaker.

The recommended range for titratable acidity (TA) is 7.0 to $9.0 \mathrm{~g} / \mathrm{L}$. In 2016, groundcover treatments had no effect on TA where the mean among treatments was $10.1 \mathrm{~g} / \mathrm{L}$. All samples were above the recommended range in 2016. Inverse to the $\mathrm{pH}$ results, the TA in 2017 was significantly lower than in 2016 and TA values fell to within the recommended ranges (Table 1). Trt 3 was the only groundcover that affected TA when compared to the control. Even though some statistical differences were seen amongst the treatments in 2017, all values were still in the acceptable range.

\subsection{Soil Analysis}

Soil samples were collected in the late winter of 2015 , 2016, and 2017 at a depth of $30 \mathrm{~cm}$. Samples were tested for a variety of factors including: $\mathrm{pH}$, organic matter, bulk density, cation exchange capacity (CEC), nitrate $\left(\mathrm{NO}_{3}\right)$, phosphorus $(\mathrm{P})$, potassium $(\mathrm{K})$, calcium $(\mathrm{Ca})$, magnesium $(\mathrm{Mg})$ and zinc $(\mathrm{Zn})$. Each of these elements is essential to grapevine health and fruit quality. A soil pH of 5.5 to 6.5 is considered optimum for wine grapes and allows for more efficient absorption of nutrients than in soils that are more alkaline or acidic [19]. Vines will grow in a wider $\mathrm{pH}$ range of 4.0 to 8.5 , but a $\mathrm{pH}$ below 5.5 and above 8 will decrease yields and hinder vine health. Soil $\mathrm{pH}$ levels were not different in any of the years so the data were averaged to acquire a single $\mathrm{pH}$ value for the three years. Trt 4 had higher $\mathrm{pH}$ than all of the other treatments (Table 2), however it still fell within the recommended range of optimal $\mathrm{pH}$. Overall, the soil of each groundcover treatment fell within the recommended range for optimal grapevine growth.

Table 2. Average soil pH, organic matter, cation exchange capacity (CEC), Phosphorus (P), Potassium (K), Calcium (Ca), Magnesium (Mg), Sodium (Na) and Zinc (Zn) concentrations from 2015, 2016 and 2017.

\begin{tabular}{|c|c|c|c|c|c|c|c|c|}
\hline Treatment & pH & $\% \mathrm{OM}$ & CEC (meq/100g) & $P(p p m)$ & K (ppm) & Ca (ppm) & Mg (ppm) & Zn (ppm) \\
\hline Trt 1 & $6.1 \mathrm{a}$ & $2.3 \mathrm{a}, \mathrm{d}$ & $26.4 \mathrm{a}$ & $13.4 \mathrm{a}, \mathrm{c}$ & $215.7 \mathrm{a}, \mathrm{c}$ & $3455.4 \mathrm{a}$ & $674.0 \mathrm{a}, \mathrm{d}$ & $2.5 \mathrm{a}$ \\
\hline Trt 2 & $6.1 \mathrm{a}$ & $2.5 \mathrm{~b}$ & $26.2 \mathrm{a}$ & $17.5 \mathrm{~b}, \mathrm{c}$ & $243.0 \mathrm{~b}, \mathrm{~d}$ & $3232.9 \mathrm{a}$ & $662.7 \mathrm{a}, \mathrm{c}, \mathrm{d}$ & $2.2 \mathrm{a}$ \\
\hline Trt 3 & $6.1 \mathrm{a}$ & $2.4 \mathrm{c}, \mathrm{d}$ & $25.8 \mathrm{a}$ & $12.2 \mathrm{a}$ & $218.8 \mathrm{a}, \mathrm{c}$ & $3285.9 \mathrm{a}$ & $617.1 \mathrm{~d}$ & $2.0 \mathrm{a}$ \\
\hline Trt 4 & $6.3 \mathrm{~b}$ & $2.2 \mathrm{a}$ & $25.8 \mathrm{a}$ & $14.3 \mathrm{a}, \mathrm{c}$ & $200.0 \mathrm{c}$ & $3351.3 \mathrm{a}$ & $689.6 \mathrm{c}, \mathrm{e}$ & $1.5 \mathrm{a}$ \\
\hline Control & $6.1 \mathrm{a}$ & $2.2 \mathrm{a}$ & $26.5 \mathrm{a}$ & $15.1 \mathrm{a}, \mathrm{c}$ & $227.8 \mathrm{a}, \mathrm{d}$ & $3298.5 \mathrm{a}$ & 717.9 a,e & $2.2 \mathrm{a}$ \\
\hline
\end{tabular}

*Values with the same letter in the same column indicate no statistical differences at $p \leq 0.05$.

Soil organic matter $(\mathrm{OM})$ is important because it improves moisture retention, soil fertility, reduces compaction and overall soil structure. The optimal level of organic matter for wine grapes is $2-3 \%$. Nitrogen is released from $\mathrm{OM}$ at roughly $9 \mathrm{~kg}$ of $\mathrm{N}$ per acre for each $1 \%$ of OM present [34]. If $\mathrm{OM}$ is too high, grapes tend to be less winter hardy because excess nitrogen promotes vegetative growth too late into the fall, not allowing vines to acclimate for winter. Similar to $\mathrm{pH}$, there were no differences in $\mathrm{OM}$ between the three years of data collection, so values were combined. OM values all fell within the recommended range of $2-3 \%$ with some minor statistical differences between treatments. The control and Trt 4 had the lowest OM, which was expected as there was less vegetation present in these plots.

Cation exchange capacity (CEC) is basically the soil's capability to hold nutrients. Each soil type will have a unique CEC, for example, fine-textured clay soils will have a CEC around $25 \mathrm{meq} / 100 \mathrm{~g}$ of soil. The greater the clay and organic matter content of the soil, the higher the CEC. Nutrient levels and $\mathrm{pH}$ tend to be more stable in soils with higher CEC. CEC 
levels below $6 \mathrm{meq} / 100 \mathrm{~g}$ of soil may have rapid changes in $\mathrm{K}, \mathrm{Ca}$ and $\mathrm{Mg}$ [35]. CEC levels were similar throughout the three years and all stayed right around the $25 \mathrm{meq} / 100 \mathrm{~g}$ of soil level with no differences among treatments (Table 2).

The recommended range for nitrate $\left(\mathrm{NO}_{3}\right)$ levels in the vineyard is generally between $9-27 \mathrm{~kg} /$ acre $(5-15 \mathrm{ppm})$ for self-rooted American and hybrid grapevines. Grapevines that are grown in soils with excess nitrogen levels may become overly vigorous which can lead to reduced fruit quality, higher disease incidence and reduced winter hardiness. Generally, all $\mathrm{NO}_{3}$ levels were below the recommended rates for American and hybrid wine grapes throughout the three years. In 2016 and 2017, Trt 1 had significantly higher $\mathrm{NO}_{3}$ rates than all other treatments (Table 3 ) and was the only groundcover treatment that had $\mathrm{NO}_{3}$ rates within the recommended range. This was expected because Trt 1 contained nitrogen fixing species such as Birdsfoot Trefoil and Dutch clover. It is also important to note that soil samples were collected at a depth of only $30 \mathrm{~cm}$ and nitrate readily leaches down into the soil profile; so it is conceivable that $\mathrm{NO}_{3}$ levels were higher deeper in the soil.

Table 3. Soil nitrate $\left(\mathrm{NO}_{3}\right)$ levels collected from vineyard soil samples from 2015 to 2017.

\begin{tabular}{llll}
\hline \multirow{2}{*}{ Treatment } & \multicolumn{4}{l}{ Soil NO } & Concentration (ppm) \\
\cline { 2 - 4 } & $\mathbf{2 0 1 5}$ & $\mathbf{2 0 1 6}$ & $\mathbf{2 0 1 7}$ \\
\hline Trt 1 & $2.4 \mathrm{a}$ & $7.4 \mathrm{a}$ & $8.0 \mathrm{a}$ \\
Trt 2 & $5.4 \mathrm{a}$ & $1.8 \mathrm{~b}$ & $1.2 \mathrm{~b}$ \\
Trt 3 & $2.6 \mathrm{a}$ & $3.4 \mathrm{a}$ & $3.2 \mathrm{~b}$ \\
Trt 4 & $2.4 \mathrm{a}$ & $1.6 \mathrm{~b}$ & $1.0 \mathrm{~b}$ \\
Control & $3.4 \mathrm{a}$ & $2.6 \mathrm{~b}$ & $1.2 \mathrm{~b}$ \\
\hline
\end{tabular}

*Values with the same letter in the same column indicate no statistical differences at $p \leq 0.05$.

The recommended range is $\mathrm{P} 40-50 \mathrm{ppm}, \mathrm{K} 250-300 \mathrm{ppm}$, Ca 500-2000 ppm, Mg 100-250 ppm, and Zn around 2 ppm. Soil samples collected in all treatments were drastically below the recommended range for $\mathrm{P}$ (12.2 to $17.5 \mathrm{ppm})$. Trt 3 had the lowest $\mathrm{P}$ values, while Trt 2 had the highest concentration. Potassium was also below the recommended range in all treatments, but not as severely as P. Trt 4 had the lowest $\mathrm{K}$ levels at just $200 \mathrm{ppm}$ and was the only treatment that was different from the control (Table 2). $\mathrm{Ca}$ and $\mathrm{Mg}$ were both well above the recommended ranges. Trt 3 exhibited lower $\mathrm{Mg}$ concentrations than the control, which would actually be a positive in this case, however it was still considerably higher than the recommended range. $\mathrm{Zn}$ hovered right around the recommended $2 \mathrm{ppm}$ for vineyard soil samples.

\section{Discussion}

All groundcover treatments established quickly, which was positively influenced by the supplemental irrigation. The groundcovers had higher stand density than the herbicide sprayed strip and natural vegetation inter-row (control). Stand density is important because it directly reduces run-off and increases infiltration of rainfall [12]. In 2015, heavy rainfall events caused severe soil erosions throughout the vineyard. This was more pronounced in areas without groundcovers where $30 \mathrm{~cm}$ gullies were carved into the ground. Conversely, the areas that were planted to groundcovers had very little to no soil erosion following the heavy rains.

Grapevine water status is an important variable of vine performance and juice/wine characteristics [36]. Water management is an important tool for regulating grapevine productivity and improving wine composition. In many Midwestern vineyards irrigation is not used after year two or three of planting because spring and occasional summer rains are sufficient to maintain adequate grapevine water status. However, non-irrigated vineyards can occasionally face water stress during extended drought periods in the growing season [37]. Soil water deficit can have negative impact on berry sugar accumulation, particularly in heavily cropped grapevines [38] such as 'Edelweiss'. In this study, midday leaf water potential $\left(\Psi_{\mathrm{md}}\right)$ was measured and used to assess the water competition taking place between the groundcover species and the neighboring grapevines. In 2015 and 2016 (i.e., the second and third growing year), there were no differences in $\Psi_{\text {md }}$ between the groundcover treatments and the herbicide sprayed control. In both of these years above average spring rainfall occurred which allowed the vines to grow unimpeded alongside their neighboring groundcovers. In 2017, the vines growing with groundcovers all showed a decrease in $\Psi_{\mathrm{md}}$ as the season progressed. The herbicide sprayed control also decreased during the dry period of summer but never had lower $\Psi_{\mathrm{md}}$ than groundcover treatments. This is an indication that during extended periods without precipitation vines growing without the added pressure of groundcovers will experience less severe water stress and will recover more quickly when the precipitation returns. In this study, we did not measure soil moisture content and its relationship to water use by grass/vegetation covered soil versus bare soil; but past research has shown that cover crops will have higher evapotranspiration rates than bare soil [12, 39]. Other perennial crops have also exhibited depressed vegetative growth when exposed to permanent groundcovers, despite the greater water infiltration that occurs with a groundcover versus bare soil [40].

In our study, vine growth was severely impacted by groundcovers in all treatments. The most pronounced case was Trt 2 (Hard Fescue, Sheeps Fescue, Sideoats Grama, Buffalo Grass, and Blue Grama) where vines actually had a decrease in pruning weights from 2015 to 2016. Many of the vines in this treatment did not even have canes to prune and weigh. The visual differences in the vines growing within this native grass groundcover was also easily recognized. Throughout growing season, the canopy of these vines never came close to reaching the ground, while the control vines had a full dense canopy that touched the ground by midseason. The $\Psi_{\text {md }}$ data taken throughout this study do not explain this drastic effect on vine growth. Other factors to consider that can contribute to the suppression of vegetative 
growth include: grapevine rooting patterns, vine age, seasonal differences in climate, and allelopathic effects of the native grass species used in the groundcover mix. This significant suppression of vine growth, particularly with the native grass groundcover, was accompanied by a similar decrease in yield. These vines produced 133\% less fruit compared to the herbicide sprayed control. This reduction in fruit relates directly to the decreased number of clusters, which often is attributed to inadequate cluster initiation caused by water stress at bloom and/or berry set [41]. However, in this study there was no indication of water stress at these key grapevine growth stages. An alternative explanation for the drastic decrease in vine growth and yield caused by the native grass groundcover while less pronounced differences were seen amongst the other groundcovers is an allelopathic effect of the grass species included in the mixture. In a previous study, Bokhari, U. [42] showed that Blue Grama (a grass used in our study) litter and fresh material exhibited a phytotoxic effect and inhibited the germination of other grass seed. Little work has been done examining allelopathic effects of native grasses on woody plant species but this could certainly explain the drastic reduction of vine growth within this treatment.

\section{Conclusion}

Overall, permanent native species groundcovers effectively reduced excessive vine growth of 'Edelweiss' grapevines in a Midwestern sample vineyard. The groundcover containing native prairie grasses had the most significant effect on vine growth, reducing pruning weights up to $193 \%$ and yields by $133 \%$ (in 2017), and can therefore not be recommended for vineyard use. The groundcover treatment that showed the most promise by not overly reducing yields was Trt 3 (i.e., Kentucky Bluegrass, White Clover, Red Fescue, Hard Fescue, Chewings Fescue, and Perennial Rye). This groundcover was quick to establish, maintained a high stand density, and could be easily maintained without negatively affecting yield and fruit quality. These attributes make Trt 3 a reasonable option to eliminate the chemically-controlled weed free strip under the grapevines. The presented results further support previous studies' recommendation that groundcovers should be planted in year two. Eliminating competition in the first year of establishment allows the vines to grow more vigorously and to become better prepared for the groundcover competition.

\section{Acknowledgements}

This paper is based on research that was partially supported by the Nebraska Specialty Crop Block Grant Program as well as the Nebraska Agricultural Experiment Station, which received funding from the Hatch Multistate Research Fund (Accession Number NEB-22-391) by the USDA National Institute of Food and Agriculture.

\section{References}

[1] Baker, N. T. (2017). Estimated annual agricultural pesticide use by crop group for states of the conterminous united states, 1992-2014.

[2] Fritschi, L., et al. (2015). Carcinogenicity of tetrachlorvinphos, parathion, malathion, diazinon, and glyphosate. The Lancet Oncology, 114 (16.5), 490-491.

[3] Jayasumana, C., Gunatilake, S., \& Senanayake, P. (2014). Glyphosate, hard water and nephrotoxic metals: Are they the culprits behind the epidemic of chronic kidney disease of unknown etiology in sri lanka? International journal of environmental research and public health, 11 (2), 2125-2147.

[4] Lennartz, B., Louchart, X., Voltz, M., \& Andrieux, P. (1997). Diuron and simazine losses to runoff water in mediterranean vineyards. Journal of Environmental Quality, 26 (6), 14931502 .

[5] Chahal, P. S., Varanasi, V. K., Jugulam, M., \& Jhala, A. J. (2017). Glyphosate-resistant palmer amaranth (amaranthus palmeri) in nebraska: Confirmation, epsps gene amplification, and response to post corn and soybean herbicides. Weed Technology, 31 (1), 80-93.

[6] Steenwerth, K., \& Belina, K. (2008). Cover crops enhance soil organic matter, carbon dynamics and microbiological function in a vineyard agroecosystem. Applied soil ecology, 40 (2), 359-369.

[7] Atucha, A., et al. (2013). Soil erosion, runoff and nutrient losses in an avocado (persea americana mill) hillside orchard under different groundcover management systems. Plant and soil, 368 (1-2), 393-406.

[8] Blavet, D., et al. (2009). Effect of land use and management on the early stages of soil water erosion in french mediterranean vineyards. Soil and Tillage Research, 106 (1), 124-136.

[9] Pool, R., Dunst, R., \& Lakso, A. (1990). Comparison of sod, mulch, cultivation, and herbicide floor management practices for grape production in nonirrigated vineyards. Journal of the American Society for Horticultural Science, 115 (6), 872-877.

[10] Tan, S., \& Crabtree, G. D. (1990). Competition between perennial ryegrass sod and chardonnay'wine grapes for mineral nutrients. HortScience, 25 (5), 533-535.

[11] Shaulis, N., \& Steel, R. (1969). Interaction of resistant rootstock to the nitrogen, weed control, pruning and thinning effects on the productivity of concord grapevines. Proc Amer Soc Hort Sci,

[12] Giese, G., Velasco-Cruz, C., Roberts, L., Heitman, J., \& Wolf, T. K. (2014). Complete vineyard floor cover crops favorably limit grapevine vegetative growth. Scientia horticulturae, 170, 256-266.

[13] Keller, M. (2015). The science of grapevines: Anatomy and morphology.

[14] Dokoozlian, N., \& Kliewer, W. (1995). The light environment within grapevine canopies. I. Description and seasonal changes during fruit development. American Journal of Enology and Viticulture, 46 (2), 209-218. 
[15] Chorti, E., Guidoni, S., Ferrandino, A., \& Novello, V. (2010). Effect of different cluster sunlight exposure levels on ripening and anthocyanin accumulation in nebbiolo grapes. American Journal of Enology and Viticulture, 61 (1), 23-30.

[16] Scheiner, J. J., Heuvel, J. E. V., Pan, B., \& Sacks, G. L. (2011). Modeling impacts of viticultural and environmental factors on 3-isobutyl-2-methoxypyrazine in cabernet franc grapes. American Journal of Enology and Viticulture, ajev. 2011.11002

[17] Byrne, M. E., \& Howell, G. S. (1978). Initial response of baco noir grapevines to pruning severity, sucker removal, and weed control. American Journal of Enology and Viticulture, 29 (3), 192-198

[18] Austin, C. N., \& Wilcox, W. F. (2011). Effects of fruit-zone leaf removal, training systems, and irrigation on the development of grapevine powdery mildew. American Journal of Enology and Viticulture, 62 (2), 193-198.

[19] Smart, R., \& Robinson, M. (1991). Sunlight into wine: A handbook for winegrape canopy management. Winetitles.

[20] Bavougian, C. M. (2014). Groundcovers and mulches for sustainable vineyard floor management The University of Nebraska - Lincoln].

[21] Bordelon, B. P., \& Weller, S. C. (1997). Preplant cover crops affect weed and vine growth in first-year vineyards. HortScience, 32 (6), 1040-1043.

[22] Loseke, B. A., Read, P. E., \& Blankenship, E. E. (2015). Preventing spring freeze injury on grapevines using multiple applications of amigo oil and naphthaleneacetic acid. Scientia horticulturae, 193, 294-300.

[23] Matthews, M. A., \& Anderson, M. M. (1989). Reproductive development in grape (vitis vinifera 1.): Responses to seasonal water deficits. American Journal of Enology and Viticulture, $40(1), 52-60$.

[24] Reynolds, A. G., \& Naylor, A. P. (1994). Pinot noir'andriesling'grapevines respond to water stress duration and soil water-holding capacity. HortScience, 29 (12), 1505-1510.

[25] Ferreyra, E., Sellés, V., Ruiz, S., \& Sellés, M. (2003). Efecto del estrés hídrico aplicado en distintos períodos de desarrollo de la vid cv. Chardonnay en la producción y calidad del vino. Agricultura Técnica, 63 (3), 277-286.

[26] dos Santos, T. P., et al. (2003). Partial rootzone drying: Effects on growth and fruit quality of field-grown grapevines (vitis vinifera). Functional Plant Biology, 30 (6), 663-671.

[27] Girona, J., et al. (2006). The use of midday leaf water potential for scheduling deficit irrigation in vineyards. Irrigation Science, 24 (2), 115-127.

[28] Williams, L., Dokoozlian, N., \& Wample, R. (1994). Handbook of environmental physiology of fruit crops. Vol i: Temperate crops.

[29] Williams, L., \& Araujo, F. (2002). Correlations among predawn leaf, midday leaf, and midday stem water potential and their correlations with other measures of soil and plant water status in vitis vinifera. Journal of the American Society for Horticultural Science, 127 (3), 448-454.

[30] Choné, X., Van Leeuwen, C., Chéry, P., \& Ribéreau-Gayon, P. (2001). Terroir influence on water status and nitrogen status of non-irrigated cabernet sauvignon (vitis vinifera). Vegetative development, must and wine composition (example of a medoc top estate vineyard, saint julien area, bordeaux, 1997). South African Journal of Enology Viticulture, 22 (1), 8-15.

[31] Grimes, D., \& Williams, L. (1990). Irrigation effects on plant water relations and productivity of thompson seedless grapevines. Crop Science, 30 (2), 255-260.

[32] Dobrowski, S., Ustin, S., \& Wolpert, J. (2003). Grapevine dormant pruning weight prediction using remotely sensed data. Australian Journal of Grape and Wine Research, 9 (3), 177-182.

[33] Dharmadhikari, M. R., \& Wilker, K. L. (2001). Micro vinification: A practical guide to small scale wine production. Midwest Viticulture and Enology Center, Dept. of Fruit Science, Southwest Missouri State University.

[34] Wolf, T. K. (2008). Wine grape production guide for eastern north america.

[35] Brown, D. (2013). Soil sampling vineyards and guidelines for interpreting the soil test results. Michigan State University Extension. Retrieved 2/15/08 from http://msue.anr.msu.edu/news/soil_sampling_vineyards_and_g uidelines_for_interpreting_the_soil_test_resul

[36] Jackson, D., \& Lombard, P. (1993). Environmental and management practices affecting grape composition and wine quality-a review. American Journal of Enology and Viticulture, 44 (4), 409-430.

[37] Hayhoe, K., et al. (2007). Past and future changes in climate and hydrological indicators in the us northeast. Climate Dynamics, 28 (4), 381-407.

[38] Poni, S., Lakso, A. N., Turner, J. R., \& Melious, R. E. (1994). Interactions of crop level and late season water stress on growth and physiology of field-grown concord grapevines. American Journal of Enology and Viticulture, 45 (2), 252-258.

[39] Bremer, D. J. (2003). Evaluation of microlysimeters used in turfgrass evapotranspiration studies using the dual-probe heatpulse technique. Agronomy Journal, 95 (6), 1625-1632.

[40] Celette, F., Gaudin, R., \& Gary, C. (2008). Spatial and temporal changes to the water regime of a mediterranean vineyard due to the adoption of cover cropping. European Journal of Agronomy, 29 (4), 153-162.

[41] Tesic, D., Keller, M., \& Hutton, R. J. (2007). Influence of vineyard floor management practices on grapevine vegetative growth, yield, and fruit composition. American Journal of Enology and Viticulture, 58 (1), 1-11.

[42] Bokhari, U. (1978). Allelopathy among prairie grasses and its possible ecological significance. Annals of Botany, 42 (1), 127-136. 